\title{
First record of a southern elephant seal (Mirounga leonina) in Sri Lankan waters
}

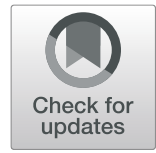

Asha de $\operatorname{Vos}^{1,2}$

\begin{abstract}
An unusual sighting of a juvenile southern elephant seal (Mirounga leonina), outside its typical range, was recorded off the southern coast of Sri Lanka between 20th November and 20th December 2019. The individual, a male as confirmed by the presence of a prepuce, underwent a catastrophic moult during this 1 month period, following which no further observations were recorded and so it was assumed it returned to sea. This represents the first confirmed sighting of a southern elephant seal, and indeed a phocid, in Sri Lankan waters.
\end{abstract}

Keywords: Northern Indian Ocean, Dispersal, Southern elephant seal, Moulting, Mirounga leonina

\section{Background}

The southern elephant seal (Mirounga leonina) typically has a circumpolar distribution around the south pole (Bailleul et al. 2007; Hindell and Mcmahon 2000) and visits the sub-Antarctic islands to breed between September-November. There are four main breeding colonies; South Georgia, Peninsula Valdez, Iles Kerguelen and Heard Island, and Macquarie Island (de Bruyn et al. 2009). Following breeding, they are known to moult mostly during December to February (Condy 1979). The adult seals disperse widely covering several thousand kilometers while spending more than 10 months of the year at sea (Bailleul et al. 2007; Hindell and Mcmahon 2000). As such, long range foraging trips are typical for southern elephant seals, with vagrants occasionally observed beyond the normal dispersal range of the species (Páez-Rosas et al. 2018).

To date, the only confirmed record of a southern elephant seal within the northern Indian Ocean is limited to a specimen collected off Oman in 1989 which was identified by its skull (Johnson 1990). Prior to that, the northernmost record from this

Correspondence: asha@oceanswell.org

'Oceanswell, 9, Park Gardens, Colombo 5, Sri Lanka

${ }^{2}$ Oceans Institute, University of Western Australia, Fairway, Crawley, WA 6009, Australia

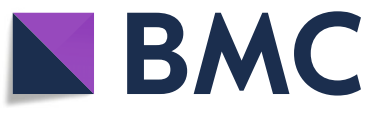

ocean basin was from Mauritius in 1955 (King 1964) (Fig. 1).

This record represents the first confirmed documentation of a southern elephant seal within Sri Lankan waters. It also represents the first record of a phocid within these waters.

\section{Results and discussion}

On 20th November 2019, a juvenile southern elephant seal was spotted in the waters off Dalawella beach, Unawatuna, southern Sri Lanka. The seal was initially spotted swimming alongshore before hauling out on the beach for a few hours. Three days later the same individual was spotted hauled out on the rocks at Midigama, approximately $15 \mathrm{~km}$ further south. The individual remained for at least 3-4h until the authorities attempted to capture it to do health assessments, which resulted in the animal returning to sea. However, based on visual assessments the animal, approximately $6 \mathrm{ft}$. in length, was in good body condition as evidenced by its broad body and fat neck (confirmed by Dr. Claire Simeone). There was some scarring that resembled cookie cutter shark bites but otherwise the individual did not appear sick or injured. Photographs from the 7th of

(c) The Author(s). 2021 Open Access This article is licensed under a Creative Commons Attribution 4.0 International License, which permits use, sharing, adaptation, distribution and reproduction in any medium or format, as long as you give appropriate credit to the original author(s) and the source, provide a link to the Creative Commons licence, and indicate if changes were made. The images or other third party material in this article are included in the article's Creative Commons licence, unless indicated otherwise in a credit line to the material. If material is not included in the article's Creative Commons licence and your intended use is not permitted by statutory regulation or exceeds the permitted use, you will need to obtain permission directly from the copyright holder. To view a copy of this licence, visit http://creativecommons.org/licenses/by/4.0/. 


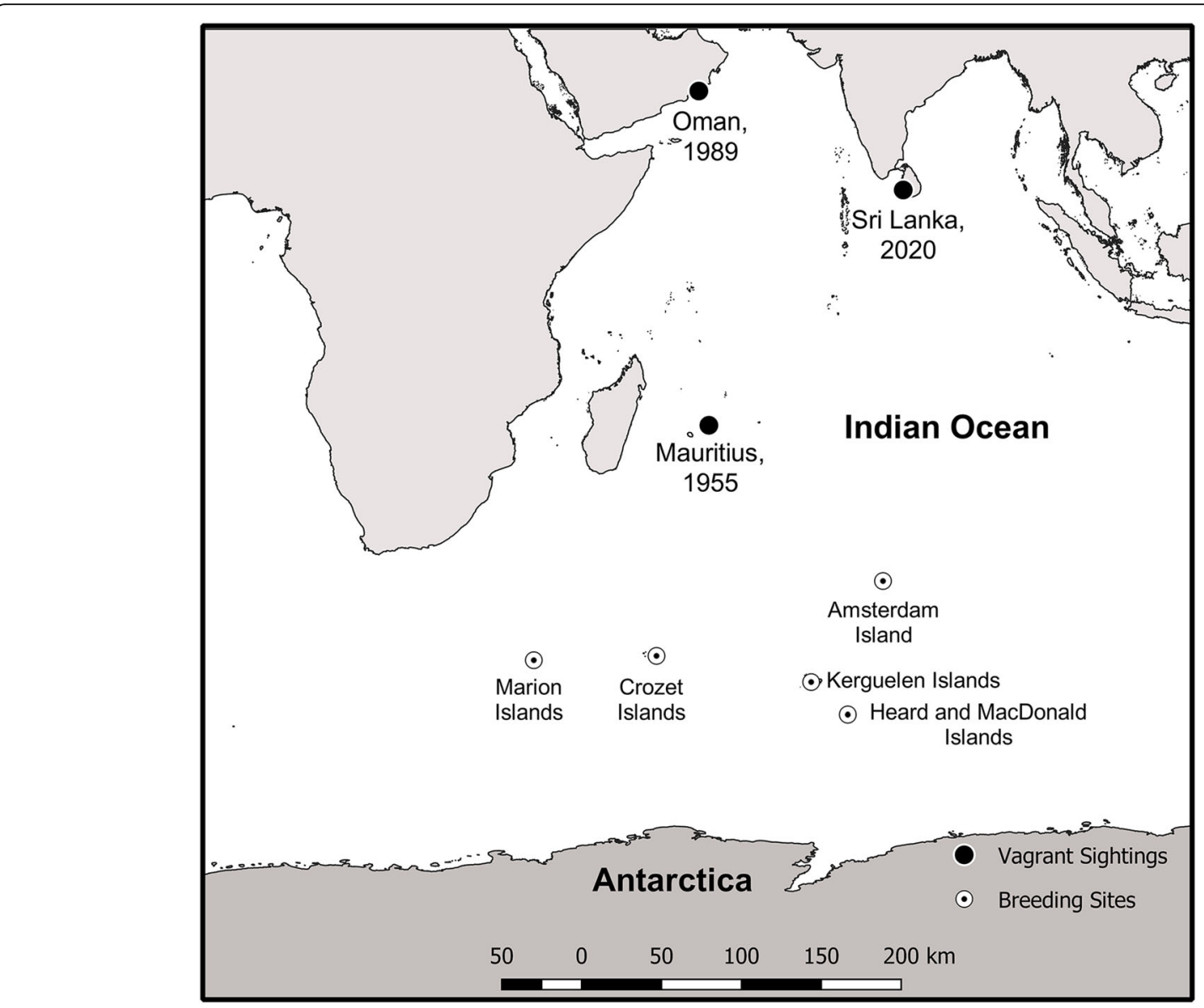

Fig. 1 Known southern elephant seal breeding sites and vagrant sightings within the Indian Ocean

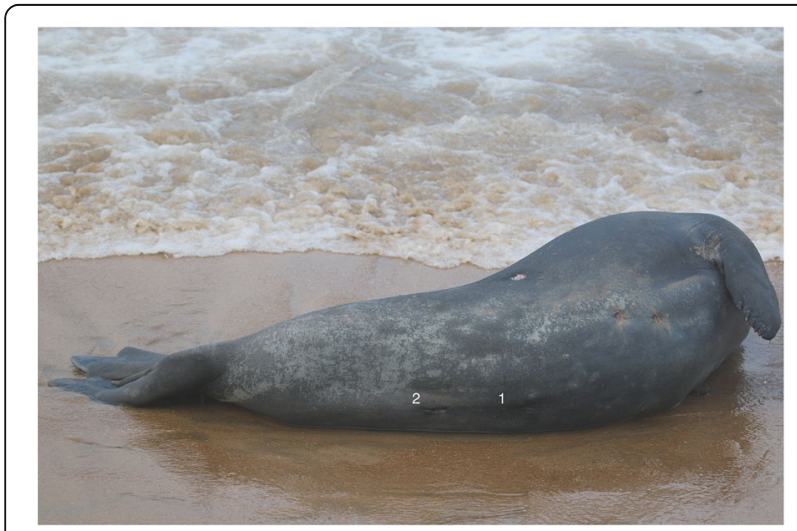

Fig. 2 Presence of $1=$ umbilicus and $2=$ prepuce, indicating that this individual was a male elephant seal
December confirmed that this animal was a male based on the presence of both an umbilicus and prepuce (Fig. 2).

Over the month (20th November - 20th December 2019), this individual was observed at 11 different locations along a $172 \mathrm{~km}$ stretch of the coastline, starting in the south and moving in a generally northerly direction along the west coast (Fig. 3). During this period it underwent a catastrophic moult, so called because of the abruptness of the process of shedding and replacement of both the hair and top layers of the epidermis (Hindell et al. 1994).

Female seals tend to return to breeding grounds to moult while mature and sub-adults males typically either return to breeding grounds or migrate to other locations in the Antarctic and sub-Antarctic regions (Setsaas et al. 2007; Slip et al. 1992). The southern elephant seal generally fasts during the moulting period surviving by exploiting the energy in its blubber reserves which have been stocked during the 


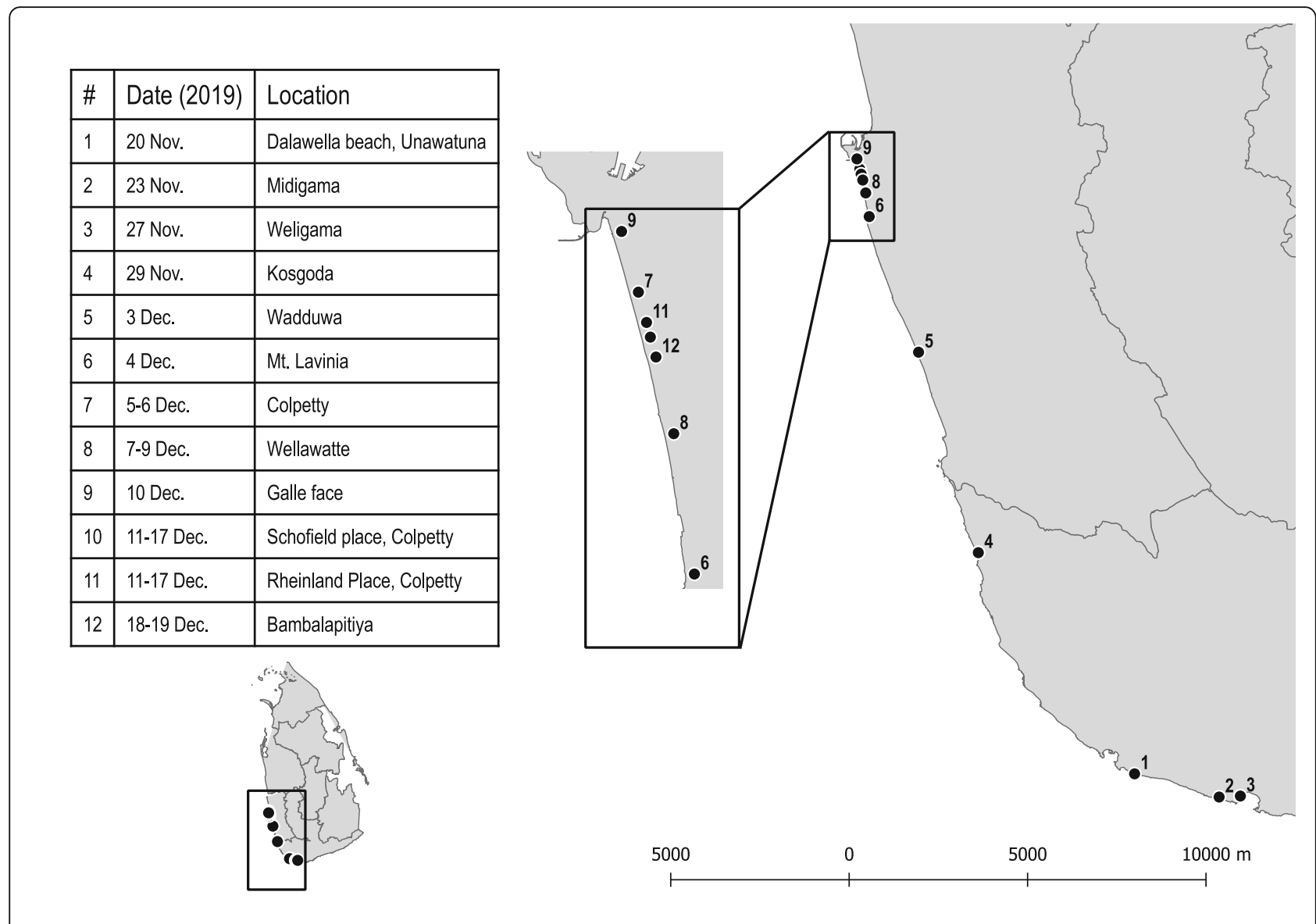

Fig. 3 Juvenile southern elephant seal sighting locations in Sri Lanka (20th November - 20th December 2019)

extensive foraging journey (Hindell et al. 1994). According to Slip et al. (1992) the estimated body mass loss of an individual southern elephant seal during the moulting period is $23 \%$ on average, with highest recorded loss of $35 \%$. The shedding of the upper layers of the epidermis and increased blood supply to dividing cells in the epidermis results in lowered insulation effectiveness and immunity of the individual. Moulting individuals generally remain on shore for most of the moulting period (Hindell et al. 1994). In some cases however, they may move between moulting sites, spending short periods of time at sea (Slip et al. 1992). In Sri Lanka, the individual moved between sites along the coastline while also spending periods of the day hauled out on the rocks and beach interspersed with time in the ocean. Further, it was observed flipping wet sand on its body on a number of occasions (Fig. 4). Sand flipping is a multi-purpose behavioural response related to managing stress (Slip et al. 1992; Lewis and Campagna 1998) and was presumably a response to the high average air temperature of $30.5^{\circ} \mathrm{C}$ (National and local weather radar 2020), which is $25^{\circ} \mathrm{C}$ higher than within its normal moulting region.

We attempted to collect samples of moulted fur and skin from this individual for confirmation of breeding stock but were unable to do so. It is however possible, but unconfirmed, that the individual sighted in Sri Lankan waters was from one of the southern Indian Ocean breeding sites (Kerguelen, Marion, Crozet, and Heard and MacDonald islands. Some individuals also breed on Amsterdam Island) located approximately $6500 \mathrm{~km}$ directly south of Sri Lanka (Fig. 1).

\section{Conclusions}

This is the only confirmed record of a southern elephant seal, and indeed a phocid, from Sri Lankan and Northern Indian Ocean waters. It is a new record outside its expected range and adds to our knowledge on vagrants of this species. 


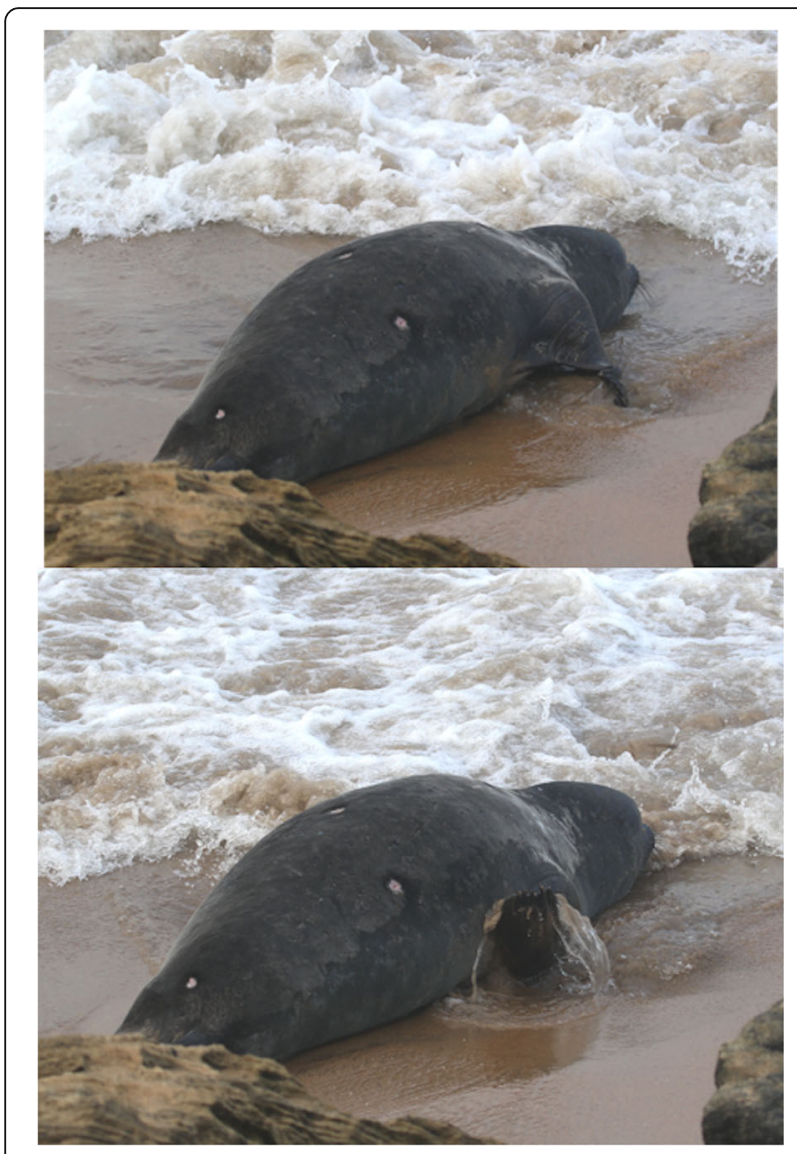

Fig. 4 The southern elephant seal in Sri Lankan waters sand flipping potentially to regulate body temperature

\section{Acknowledgements}

I wish to acknowledge the Commander of the Sri Lanka Navy, Vice Admiral Piyal De Silva for first alerting me to this sighting. Further thanks to all individuals who responded to Oceanswell's social media request for information with photos, footage and location information over subsequent days and the Department of Wildlife and Navy officers who sent information from their respective coastal areas. Thank you to the Marine Mammal mailing List community members who helped confirm species identity based on the first video and for providing other reports of vagrants, and to Dr. Claire Simeone from the Marine Mammal Center in Sausalito and Dr. Greg Hofmeyr from the Port Elizabeth museum for their valuable comments and advice in this unusual situation. Thanks also to Isuru Wijesundara and Isha Shyam for support in creating the maps for this manuscript. AdV is supported by a Pew Fellowship in Marine Conservation.

\section{Author's contributions}

AdV conducted the fieldwork, analysed the photos and wrote the paper. The author(s) read and approved the final manuscript.

\section{Funding}

AdV is supported by a Pew Fellowship in Marine Conservation.

\section{Availability of data and materials}

The datasets used and/or analysed during the current study are available from the corresponding author on reasonable request.

Ethics approval and consent to participate Not applicable.
Consent for publication

Not applicable.

\section{Competing interests}

The author declares that she has no competing interests.

Received: 8 April 2020 Accepted: 14 December 2020

Published online: 29 January 2021

\section{References}

Bailleul F, Charrassin J, Monestiez P, Roquet F, Biuw M, Guinet C. Successful foraging zones of southern elephant seals from the Kerguelen Islands in relation to oceanographic conditions. Philos T Roy Soc B. 2007;362(1487): 2169-81.

Condy PR. Annual cycle of the southern elephant seal Mirounga leonina (Linn.) at Marion Island. Afr J Mar Sci. 1979;14:95-102.

de Bruyn M, Hall B, Chauke L, Baroni C, Koch P, Hoelzel A. Rapid response of a marine mammal species to holocene climate and habitat change. PLoS Genet. 2009;5(7):e1000554.

Hindell M, Mcmahon C. Long distance movement of a southern elephant seal (Mirounga leonina) from Macquarie Island to Peter 1 Oy. Mar Mammal Sci. 2000;16(2):504-7.

Hindell M, Slip D, Burton H. Body mass loss of moulting female southern elephant seals, Mirounga leonina, at Macquarie Island. Polar Biol. 1994;14(4): $275-8$

Johnson D. A southern elephant seal (Mirounga leonina Linn.) in the northern hemisphere (Sultanate of Oman). Mar Mammal Sci. 1990;6(3):242-3.

King J. Seals of the world. London: British Museum (Natural History); 1964.

Lewis M, Campagna C. Flipping sand in elephant seals. Aquat Mamm. 1998;24(3): 85-90.

National and local weather radar, daily forecast, hurricane and information from The Weather Channel. 2020. http://www.weather.com. Assessed 24 Jan 2020.

Páez-Rosas D, Riofrío-Lazo M, Ortega J, Morales J, Carvajal R, Alava J. Southern elephant seal vagrants in Ecuador: a symptom of La Niña events? Mar Biodivers Rec. 2018;11(1):1-8.

Setsaas T, Bester M, van Niekerk J, Roux J, Hofmeyr G. Dispersion during the moult haulout of southern elephant seals at the Courbet peninsula, lles Kerguelen. Polar Biol. 2007;31(2):249-53.

Slip D, Gales N, Burton H. Body-mass loss, utilization of blubber and fat, and energetic requirements of male southern elephant seals, Mirounga leonina, during the molting fast. Aust J Zool. 1992;40(3):235.

\section{Publisher's Note}

Springer Nature remains neutral with regard to jurisdictional claims in published maps and institutional affiliations.

Ready to submit your research? Choose BMC and benefit from:

- fast, convenient online submission

- thorough peer review by experienced researchers in your field

- rapid publication on acceptance

- support for research data, including large and complex data types

- gold Open Access which fosters wider collaboration and increased citations

- maximum visibility for your research: over $100 \mathrm{M}$ website views per year

At $\mathrm{BMC}$, research is always in progress.

Learn more biomedcentral.com/submissions 